\title{
A simple method for detecting mycoplasma infection of cell cultures
}

\author{
G. B. HARNETT, P. A. PHILlips, AND E. M. MACKAY-SCOLLAY \\ From the Department of Microbiology, State Health Laboratory Service, Sir Charles Gairdner Hospital, \\ Shenton Park, Western Australia
}

SYNOPSIS This paper describes the overnight Giemsa staining method for detecting mycoplasma.-infection of cell cultures. This simple method requires no special equipment and has practical $\stackrel{ }{\circ}$ application in most cell culture laboratories. This technique has been used conveniently to monitor 욱 stock cell cultures for mycoplasma infection over a 12-month period avoiding any contamination.

Mycoplasma contamination of cell cultures is a widespread and variable factor which can give rise to fallacious results in many experiments. Mycoplasma infection can produce acidity and a cytopathic effect in some cells (Butler and Leach, 1964; Girardi, Hamparian, Somerson, and Hayflick, 1965), may cause chromosome changes (Paton, Jacobs, and Perkins, 1965; Fogh and Fogh, 1965), and may also affect virus growth (Singer, Ford, Barile, and Kirschstein, 1972). On occasion, mycoplasmas present in cell cultures have been mistaken for viruses (Cross, Goodman, Chatterji, Beswick, and Chapman, 1970), and as contaminating antigens in virus preparations used to immunize animals they may give rise to troublesome cross-reacting antibodies particularly in fluorescent antibody studies (Harnett, unpublished observations, 1972). We describe a simple and sensitive method for detecting mycoplasma infection of cell cultures suitable for routine testing of cultures in diagnostic and research laboratories.

\section{Materials and Methods}

\section{CULTURE MEDIA}

Powdered Eagle's basal medium (Grand Island Biological Co, NY, USA) was made up according to the manufacturer's directions. Routine growth medium for cell culture was made by supplementing this with $10 \%$ foetal calf serum, $0.07 \%$ sodium bicarbonate, 100 units of penicillin, and 100 micrograms of streptomycin. For maintenance of tube cultures in the titration experiment, foetal calf serum was reduced to $2 \%$ and sodium bicarbonate increased to $0.2 \%$. For coverslip culture, growth medium was Received for publication 23 October 1973. modified by increasing the sodium bicarbonate $\stackrel{0}{2}$ concentration to $0.14 \%$ and adding $28 \mathrm{mM} \mathrm{N}-2-\vec{\varphi}$ hydroxyethylpiperazine- $\mathrm{N}^{\prime}$-2-ethanesulphonic acid (HEPES) (Good, Winget, Winter, Connolly, Izawa, and Singh, 1966). With the foetal calf serum reduced to $2 \%$ this medium was also used for maintenance of tubes in the titration experiment.

\section{COVERSLIP CULTURES}

Cells to be tested for mycoplasma infection were $\overline{\overrightarrow{0}}$ harvested with trypsin or versene and seeded in 3 $1 \mathrm{ml}$ of growth medium into sterile, disposable, flatbottomed plastic bottles each of which contained a sterile, circular $10 \mathrm{~mm}$ diameter glass coverslip. The cell dose used was that which formed an incomplete monolayer on the coverslip after 24 hours' incubation at $36^{\circ} \mathrm{C}$.

\section{FIXATION AND STAINING}

These manoeuvres were carried out in the original vessels. Cells on coverslips were washed once with $\frac{7}{0}$ phosphate buffer pH 6.8 obtained from G T Gurr, after discarding the culture medium, and then $\sigma$ fixed for five minutes in methanol. The coverslips $N$ were then stained overnight with a 1/200 dilution of $N$ Giemsa stain (Merck) in phosphate buffer. Staining $\omega$ was followed by rinsing the coverslips for two to five minutes in phosphate buffer, after which they were removed from the bottles, air-dried, and $\stackrel{\oplus}{\oplus}$ mounted on microscope slides in DPX (G T Gurr) and examined under an oil-immersion objective at $1000 \times$ magnification.

EXPERIMENTS USING MEDIA BUFFERED BY HEPES

As HEPES buffer is widely used in cell culture 
media and there is evidence that its use in artificial media enhances growth of mycoplasma (Manchee and Taylor-Robinson, 1969; Spendlove, Crosbie, Hayes, and Keeler, 1971), it was decided to test bicarbonate and HEPES/bicarbonate buffers in a titration of mycoplasma infectivity.

A cell-free pool of Mycoplasma hyorhinis, stored as aliquots in liquid nitrogen, was prepared as tenfold dilutions in Hanks' balanced salt solution and inoculated into tube cultures of FL amnion cells (Fogh and Lund, 1957). The tubes were divided into two replicate sets and maintained respectively on bicarbonate-buffered medium and HEPES/ bicarbonate-buffered medium. After seven days' incubation the cells were harvested and seeded into coverslip culture bottles, incubated, fixed, and stained as above.

\section{Results}

The appearance of a normal uninfected FL amnion cell stained with Giemsa is shown in figure 1A. Mycoplasma appeared as dark blue to purple coccoid bodies, tending to be most numerous at the

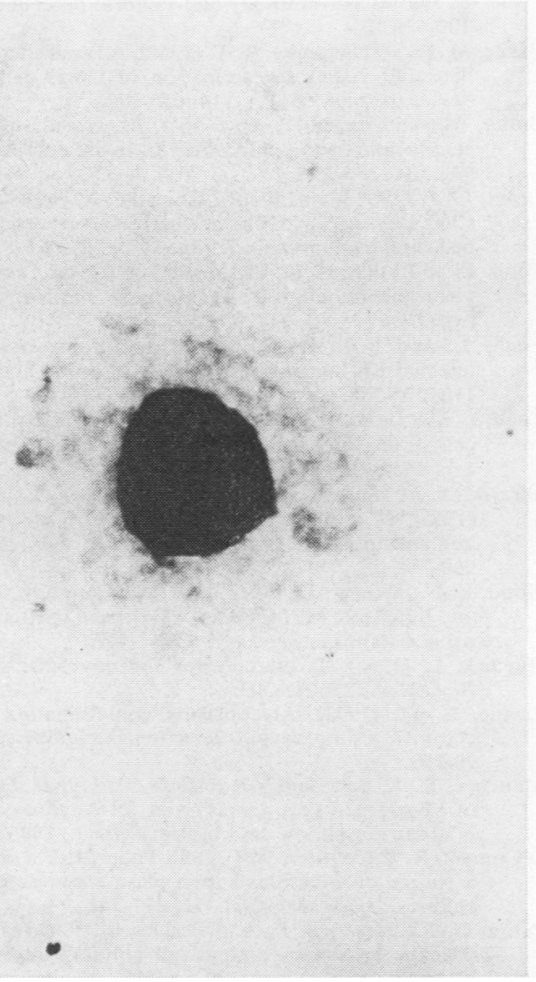

Fig 1A

Fig 1 Giemsa-stained FL amnion cells X1500: (A) uninfected; (B) infected with Mycoplasma hyorhinis. periphery of infected cells (fig 1B). Detection was for this reason facilitated by an incomplete monolayer of cells.

Growth of the mycoplasma was generally profuse and high levels of infection were attained rapidly after inoculation of susceptible cell cultures. The level of infection was apparently unaffected by subculture of the infected cells 24 hours before staining.

The results of the experiments to test the effect of different buffer systems on the titration of mycoplasma are shown in the table.

\begin{tabular}{ll}
\hline Buffer System & $T C I D_{30}$ (Reed and Muench) \\
\hline $\mathrm{NaHCO}_{3}$ & $10^{-5.801}$ \\
HEPES/NaHCO, & $10^{-6.07}$ \\
\hline
\end{tabular}

Table Fifty percent endpoint values of titration of Mycoplasma hyorhinis in FL amnion cells maintained in two different buffer systems

${ }^{1}$ Two separate titrations, total of eight (8) tubes per dilution.

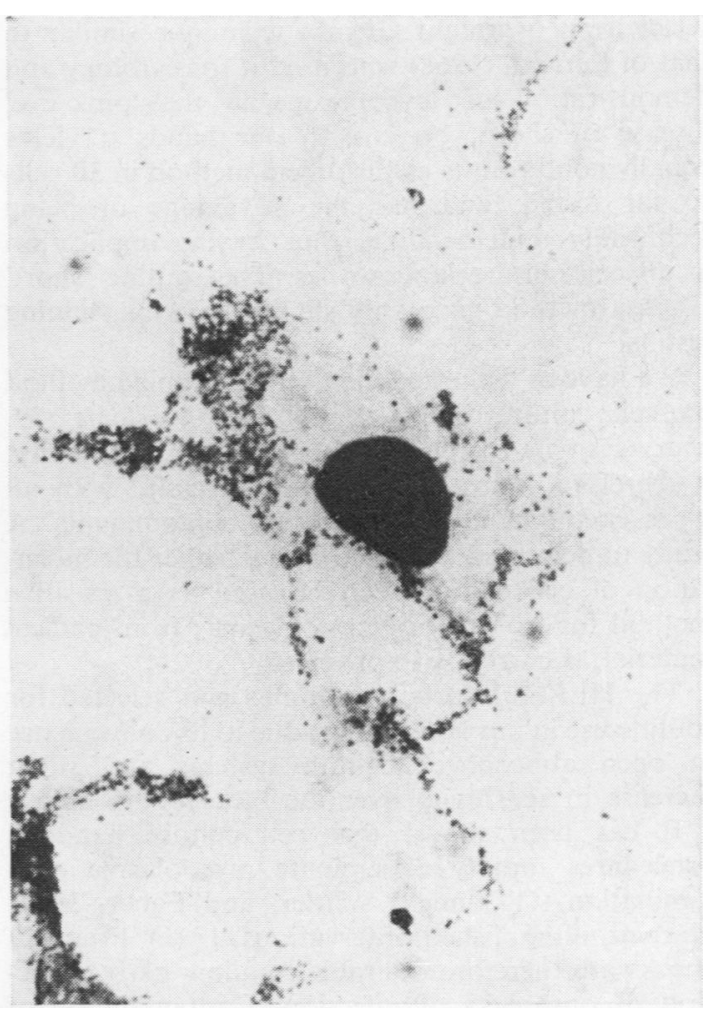

Fig 1B 


\section{Discussion}

Many methods have been described for detecting mycoplasma infection of cell cultures. They include culture on special cell-free media (Hayflick, 1965) which suffers from being slow to yield results (4-14 days) and unsatisfactory for some strains of mycoplasma; chemical methods of detection (Barile and Schimke, 1963; Levine, 1972) which require relatively large amounts of cell material, special apparatus and reagents, and rely on uniform biochemical behaviour of different mycoplasmas for success; fluorescent antibody techniques (Barile, Malizia, and Riggs, 1962) which are inconvenient to employ since they require many antisera and are unreliable in that new serotypes may be missed; and direct staining methods (Fogh and Fogh, 1964).

In our experience direct staining gives good results and constitutes an important advance on other methods because of its speed, simplicity, and sensitivity. The orcein staining method of Fogh and Fogh (1964) has the disadvantage of requiring phase contrast optics for reading results, and, although the staining procedure is rapid, it is said to work better on some cell lines than others. We selected an overnight Giemsa technique similar to that of Surman (1968) who used it for cytology and demonstration of mycoplasma in the 'pink eye' disease of sheep, because in our hands it yields equally good results as the orcein method in all cells so far tested, and has the advantage of being technically undemanding, thus having application in all cell culture laboratories. The routine 'short' Giemsa method gave only slightly inferior staining results.

We have so far tested the Giemsa staining method on cell cultures infected with $M$. hyorhinis, $M$. pharyngis type 1 , and $M$. hominis with similar results; it therefore seems likely to be successful with all types encountered as cell culture contaminants. A study to determine this, and also whether the inoculation of cell cultures can be used as a sensitive method for isolation of mycoplasmas from clinical material, is currently in progress.

The HEPES/bicarbonate buffer was selected for routine use in our laboratories due to its convenience in open atmosphere culture systems and slight increase in sensitivity over the bicarbonate buffer.

It has been shown that cell culture handling procedures rapidly disseminate mycoplasma contamination (O'Connell, Wittler, and Faber, 1964; Harnett, unpublished observations, 1971). Frequent checks are therefore desirable to allow early detection of outbreaks of infection. Contamination of standard cell lines may arise from four main sources: (1) infection from the operator with serotypes present in the respiratory tract; (2) contaminated cells or products of such cells introduced from outside laboratories (Stewart and Young, 1971); (3) contaminated animal sera used to supplement media (Barile and Kern, 1971); (4) new cell cultures derived within the laboratory from infected tissues.

Since eliminating all mycoplasma-contaminated cell lines from our laboratories, regular weekly checks using the Giemsa staining method have revealed no contamination of stock cultures over a 12-month period although $M$. hyorhinis and $M$. pharyngis type 1 have been detected in virus seeds propagated previously in mycoplasma-infected stocks and in some virus seeds and cell cultures received from external sources.

We wish to thank Dr W. S. Davidson, Commissioner for Public Health, for permission to publish this article.

\section{References}

Barile, M. F., and Kern, J. (1971). Isolation of Mycoplasma arginin from commercial bovine sera and its implication in contaminated cell cultures. Proc. Soc. exp. Biol. (N.Y.), 138, 432-437.

Barile, M. F., Malizia, W. F., and Riggs, D. B. (1962). Incidence and detection of pleuropneumonia-like organisms in cell cultures by fluorescent antibody and cultural procedures. $J$. Bact., 84, 130-136.

Barile, M. F., and Schimke, R. T. (1963). A rapid chemical method for detecting PPLO contamination of tissue cell cultures. Proc. Soc. exp. Biol. (N.Y.), 114, 676-679.

Butler, M., and Leach, R. H. (1964). A mycoplasma which induces acidity and cytopathic effect in tissue culture. J. gen. Microbiol., 34, 285-294.

Cross, G. F., Goodman, M. R., Chatterii, J., Beswick, T. S. L., and Chapman, J. A. (1970). Another case of mistaken identity: rubella and mycoplasma. J. gen. Virol., 8, 77-81.

Fogh, J., and Fogh, H. (1964). A method for direct demonstration of pleuropneumonia-like organisms in cultured cells. Proc. Soc. exp. Biol. (N. Y.), 117, 899-901.

Fogh, J., and Fogh, H. (1965). Chromosome changes in PPLOinfected FL human amnion cells. Proc. Soc. exp. Biol. (N.Y.), 119, 233-238.

Fogh, J., and Lund, R. O. (1957). Continuous cultivation of epithelial cell strain (FL) from human amniotic membrane. Proc. Soc exp. Biol. (N.Y.), 94, 532-537.

Girardi, A. J., Hamparian, V. V., Somerson, N. L., and Hayflick, L. (1965). Mycoplasma isolates from primary cell cultures and human diploid cell strains. Proc. Soc. exp. Biol. (N.Y.), 120, 760-771.

Good, E. N., Winget, G. D., Winter, W., Connolly, T. N., Izawa, S., and Singh, R. M. M. (1966). Hydrogen ion buffers for biologi-cal research. Biochemistry, 5, 467-477.

Hayflick, L. (1965). Tissue cultures and mycoplasmas. Texas Rept. Biol. Med., 23, 285-303.

Levine, E. M. (1972). Mycoplasma contamination of animal cell' cultures: a simple rapid detection method. Exp. Cell Res., 74, 99-109.

Manchee, R. J., and Taylor-Robinson, D. (1969). Enhanced growth of T-strain mycoplasmas with $\mathrm{N}$-2-hydroxyethylpiperazine$N^{\prime}$-2-ethanesulfonic acid buffer. J. Bact., 100, 78-85.

O'Connell, R. C., Wittler, R. G., and Faber, J. E. (1964). Aerosols as. a source of widespread mycoplasma contamination of tissue cultures. Appl. Microbiol., 12, 337-342.

Paton, G. R., Jacobs, J. P., and Perkins, F. T. (1965). 'Chromosome changes in human diploid-cell cultures infected with mycoplasma. Nature (Lond.), 207, 43-45.

Singer, S. H., Ford, M., Barile, M., and Kirschstein, R. L. (1972). Effect of mycoplasmas on virus replication and plaque formation in mouse cells. Proc. Soc. exp. Biol. (N. Y.), 139, 56-58. 
Spendlove, R. S., Crosbie, R. B., Hayes, S. F., and Keeler, R. F. (1971). Tricine-buffered tissue culture media for control of mycoplasma contaminants. Proc. Soc. exp. Biol. (N.Y.), 137, 258-263.

Stewart, S. M., and Young, D. (1971). Isolation of Mycoplasma arginini from tissue cultures. Lancet, 1, 347.
Surman, P. G. (1968). Cytology of 'pink eye' of sheep, including a reference to trachoma of man, by employing acridine orange and iodine stains, and isolation of mycoplasma agents from infected sheep eyes. Aust. J. Biol. Sci., 21, 447-467.

\section{The December 1973 Issue}

\section{THE DECEMBER 1973 ISSUE CONTAINS THE FOLLOWING PAPERS}

Genetic basis, epidemiology, and future significance of antibiotic resistance in Staphylococcus aureus: A review R. W. LACEY

Rapid adenovirus typing by immunoelectron microscopy P. LUTON

Urinary infection caused by Micrococcus subgroup 3 HELEN KERR

Preoperative sterilization of the perineum: A comparison of six antiseptics MARGARET E. BYATT AND A. HENDERSON

A disposable bedpan system using an improved disposal unit and self-supporting bedpans $G$. $L$. GIBSON

Metastasizing ependymoma of the cauda equina D. G. B. WIGHT, K. J. HOLLEY, AND J. A. H. FINBOW

Hepatic cirrhosis: A clinico-pathological review of 520 cases R. N. M. Macsween AND A. R. SCOTT

Inflammatory pseudo-tumours of the abdomen: plasma cell granulomas JANE P. WU, EDUARDO J. YUNIS, GEORGE FETTERMAN, WALTER F. JAESCHKE, AND ENID F. GILBERT

Fine structure and morphogenesis of spironolactone bodies in the zona glomerulosa of the human adrenal cortex $K$. KOVACS, E. HORVATH, AND W. SINGER
Human platelet reactivity during stressful diagnostic procedures J. L. GORDON, D. E. BOWYER, D. W. EVANS, AND M. J. MITCHINSON

Superiority of simplified assay for folate with Lactobacillus casei ATCC 7469 over assay with chloramphenicol-adapted strain BERNARD A. COOPER

The significance of the fluorescent treponemal antibody (FTA-ABS) test in collagen disorders and leprosy D. J. M. WRIGHT

A new mathematical model for fitting an HPL radioimmunoassay curve B. R. HARDING, RITCHIE THOMSON, AND A. R. CURTIS

\section{Technical method}

A method for bacteriological sampling of surfaces by direct application of culture media $D$. MacCULLOCH AND B. M. CORNERE

Letter to the Editor

Book reviews

The Association of Clinical Pathologists: 91st general meeting

Index to Volume 26

Contents of Volume 26

Copies are still available and may be obtained from the PUBLISHING MANAGER, BRITISH MEDICAL ASSOCIATION, TAVISTOCK SQUARE, LONDON, WC1H 9JR, price $£ 1.05$ 